\title{
Soil Ecology of a Lichen Heath at Spitsber- gen, Svalbard: Effects of Artificial Removal of the Lichen Plant Cover.
}

\author{
ERLING SENDSTAD
}

\begin{abstract}
The Norwegian MAB project conducted research on the possible effects of overgrazing in winter pastures of the Spitsbergen reindeer ( $R$. tarandus playtyrhyncus, Vrolik). In a $25-\mathrm{m}^{2}$ area of a lichen heath at Svalbard, $\left(79^{\circ} \mathrm{N}, 12^{\circ} \mathrm{E}\right)$, the lichen plant cover was artificially removed. This was done to simulate the effects of heavy grazing, resulting in the disapperance of the lichens. The experiment resulted in a significant decrease in total soil respiration. A corresponding effect was found on the population development of the Collembola species Hypogastrura tullbergi (Schaffer). This species may, therefore, be a good indicator as to the long-term effects on soil microflora. It is also shown that the population development of the different Collembola species is not regulated through Aranea predation. The removal of the lichen plant cover did effect a decrease in the soil content of organic matter and macronutrients.
\end{abstract}

The lichen heaths of Spitsbergen (Brattbakk and R $\phi$ nning 1978) represent important pastures for the Spitsbergen reindeer. Ruminant grazing has, however, in many areas of marginal rangeland, resulted in overgrazing, and consequently in increased run-off and ultimately in soil erosion and loss of nutrients (Lusby 1970, Rauzi and Hanson 1966). In areas where the potential of plant production exceeds the rate of decomposition, plant production will be regulated through the availability of essential nutrients. In such systems, it is the activity of the decomposers that regulates the whole system's productivity (Macfayden 1962 a).

In relation to these statements, it has been shown that reindeer, through their total grazing effect, i.e. ingestion and trampling, dislodged $68 \%$ of the lichens present during one summer season (Peagu 1970). In this case after one summer of grazing, $15 \%$ of the lichens were considered unusable because of trampling by reindeer (Pegau 1970). Trampling may further result in increased bulk density and consquently in decreased porosity of the soil (Smeins 1975). This may result in a reduced ability of water to penetrate into the soil. Consequently the surface run-off is increased (Rauzi et al. 1968).

These changes in the properties of vegetation and soil are also reflected in the decomposer activity in the soil. It has been shown that heavy grazing may cause a decline in soil respiration (Howard and Howard 1976) and also a reduced abundance of microbial grazers such as the Collembola (Willard 1973). It has also been recorded that changes in rates of decomposition affect the litter layer (Welch and Raws 1964).

\footnotetext{
Author is with SINTEF, Applied Chemistry Division, N-734 Trondheim-NTH, Norway.

This paper is a part of the biological investigations carried out by the Norwegian MAB project (Man and the Biosphere). I wish to thank my colleagues there for their assistance in collecting the data.

Manuscript received March 18, 1980.
}

These general statements may be of considerable concern to the management of the reindeer population on an arctic island such as Spitsbergen. This population relies during the winter on pastures that are extremely vulnerable, both as a consequence of the lichen plant cover and the concentrated run-off of melt water in the spring.

A subproject of the Norwegian "Man and the Biosphere"(MAB) programme has, therefore, been concerned with the immediate effects on soil ecology caused by an artificial removal of the lichen heath.

\section{Methods}

The lichen heath tested is located close to Ny Alesund in Spitsbergen $\left(79^{\circ} \mathrm{N}, 12^{\circ} \mathrm{E}\right)$. The lichen cover is dominated by Cetraria delisei; this range type is described by Brattbakk and $\mathrm{R} \phi$ nning (1978) from the point of view of plant sociology.

On this site an area $25 \mathrm{~m}^{2}$ was cleared of lichens. The effects on total soil respiration were registrated by an infra red gas analyser. The respiration studies were conducted at $+5^{\circ} \mathrm{C}$ and $32 \%$ water content of the soil samples, in a static experimental procedure. The respiration rates are calculated as $\mathrm{mg} \mathrm{CO} / \mathrm{m}^{2} \mathrm{hr}$ and concern the total respiration of soil samples with a diameter of $5.5 \mathrm{~cm}$ and $3 \mathrm{~cm}$ deep.

From corresponding samples, soil arthropods were extracted in a high gradient extractor (MacFayden $1962 \mathrm{~b}$ ). Data are here given as mean estimates based on twclve replicas in each sample.

The experiment started in the summer 1976 and has been recorded up until the end of the summer 1979.

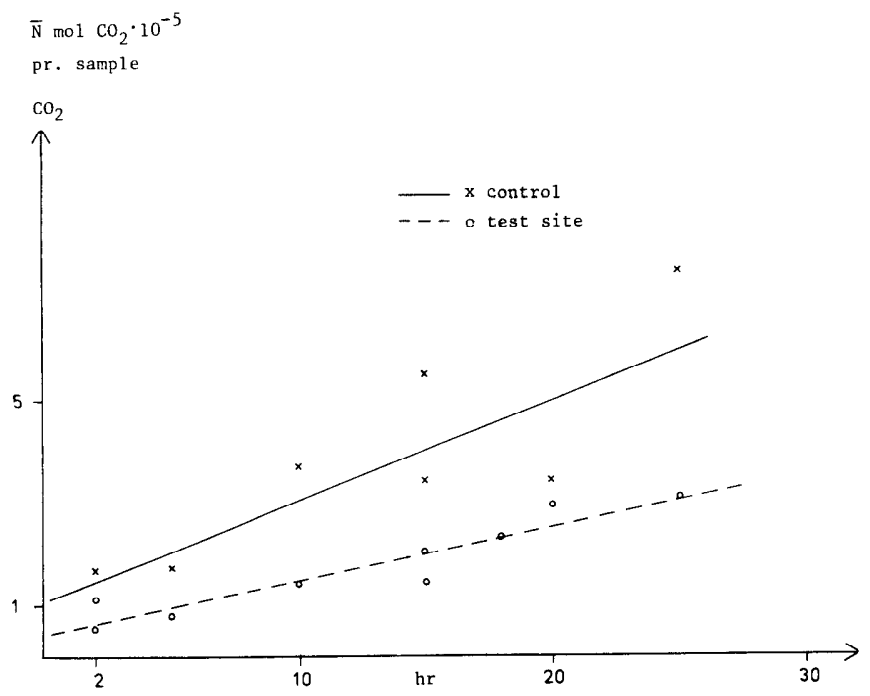

Fig. 1. Rates of respiration in the natural lichen heath and in a test site where the lichens were removed in 1976. Respiration data is from the summer, 1978. Respiration temperature $+5^{\circ} \mathrm{C}$. 


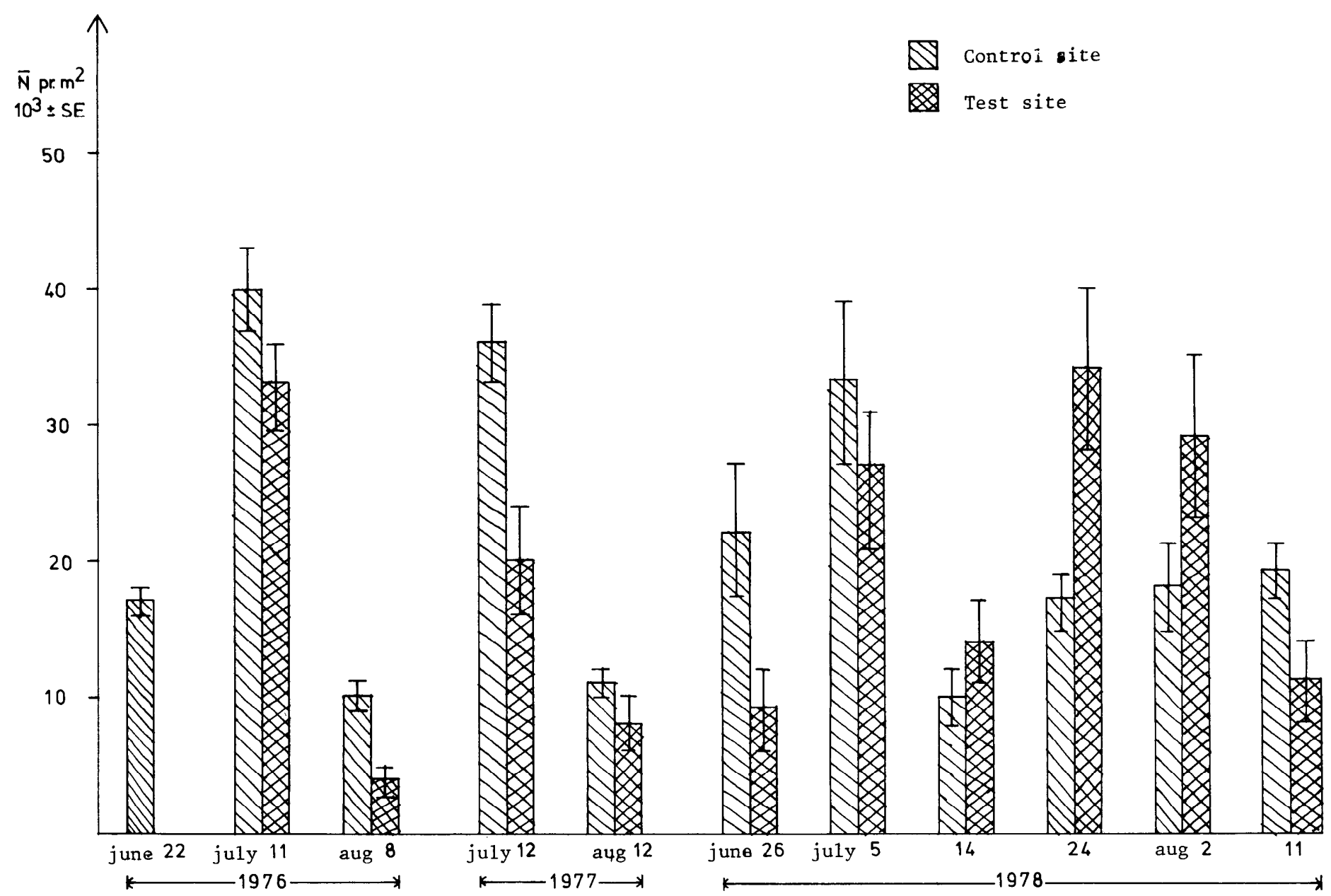

Fig. 2. Number of Collembola $( \pm S E)$ in the control and the test site. Test site; the lichen cover removed.

\section{Results}

Soil respiration in a natural (control) site of the lichen heath, during summer 1978 , is estimated to have been between $40-96 \mathrm{mg}$ $\mathrm{CO}_{2} / \mathrm{m}^{2} / \mathrm{hr}$ at $5^{\circ} \mathrm{C}$ and $32 \% \mathrm{H}_{2} \mathrm{O}$. This estimate gives the limits of the $95 \%$ confidence interval. This estimate is comparable to data given by Billings et al. (1977). There, total soil respiration in more humid soils in Alaska was estimated to produce $75-300 \mathrm{mg}$ $\mathrm{CO} / 2 / \mathrm{m}^{2} / \mathrm{hr}$ over the summer season.

The effect on soil respiration of removing the lichens is shown in Figure 1.

Figure 1 shows a significant decrease in total soil respiration (significant at the $10 \%$ level). The mean estimate declined from 68 $\mathrm{mg} \mathrm{Co} / 2 / \mathrm{m}^{2} / \mathrm{hr}$ in the control area to $35 \mathrm{mg} \mathrm{Co} / \mathrm{m}^{2} / \mathrm{hr}$ in the treatment area.

As an indication of the effects on the soil zoological community, the results from the study of Collembola are shown in Figure 2. It can be seen that initially there was a decrease in Collembola abundance. From the end of the 1977 summer, an increased $\mathrm{Col}$ lembola abundance was found, however.

When the data in Figure 2 are divided into individual species, it is demonstrated (Fig. 3) that the removal of the lichens has produced different effects for each of the two dominating Collembola species at the site: Folsomia quadrioculata (Tullberg) and Hypogastrura tullbergi (Schäffer). These two species account for about $95 \%$ of total Collembola abundance at the site.

The total effect of removing the lichen plant cover on soil erosion are shown in Table 1. A decrease in the content of organic matter and macronutrients after 4 years is demonstrated.

\section{Discussion}

These results clearly demonstrate that a severe grazing intensity that totally alters the plant cover may also severely affect the ecology of the soil. It is shown that the removal of the lichens resulted in a $50 \%$ decrease in soil respiration. This, I am inclined to conclude, will affect the rates of release of essential nutrients for further plant production.

The effects of the experiment on the two Collembola species (Fig. 3) might also have a rcasonable explanation. The decreasing species, $H$. tullbergi, is known to be a fungi grazing animal (Addison 1977). While the representatives of the genus Folsomia are reported to be primary decomposers (Whittaker 1974).

The results therefore indicate that the soil biota live together in complex relationships. It may be concluded that, while $F$. quadrioculata in many ways may be unaffected or even negatively affected by an actively growing soil microflora, the other species $\boldsymbol{H}$. $\mathbf{t u l l}$ bergi may turn out to be a relatively good indicator of the longterm activity of the soil microflora in these areas. These kinds of indicators in connection with soil ecology might be useful because the measurement of long term microbial activity is difficult and extremely time consuming.

Table 1. Chemical content of soil. Data after 4 years of exposure. Data are mean estimates, each based on a mixed sample from five replicas.

\begin{tabular}{lcccc}
\hline \hline & Dry matter \\
$\begin{array}{l}\text { Parameters } \\
\text { Test site }\end{array}$ & $\begin{array}{c}\text { Loss of } \\
\text { ignition } \\
(\%)\end{array}$ & $\begin{array}{c}\text { N (Kjeldal) } \\
(\%)\end{array}$ & $\begin{array}{c}\mathbf{P} \\
(\%)\end{array}$ \\
\hline $\begin{array}{l}\text { Control } \\
\begin{array}{l}\text { Lichen cover } \\
\text { removed }\end{array}\end{array}$ & 64.9 & 16.3 & 0.72 & 0.063 \\
\hline
\end{tabular}


Table 3. Food consumption in the Collembola community of an unaffected lichen heath at the Brögger peninsula, Spitsbergen. Data given for +5 and $+150^{\circ} \mathrm{C}$.

\begin{tabular}{lc}
\hline \hline Species & Food consumed \\
\hline F. Quadrioculata & $12.0-19.1 \mathrm{Kcal} \mathrm{M}^{-2}$ year $^{-1}$ \\
H. tullbergi & $0.7-1.1 \mathrm{Kcal} \mathrm{m}^{-2}$ year $^{-1}$ \\
Other Collembola & $1.2-2.0 \mathrm{Kcal} \mathrm{m}^{-2}$ year $^{-1}$ \\
¿Collembola & $13.3-22.2 \mathrm{Kcal} \mathrm{M}^{-2} \mathrm{year}^{-1}$ \\
\hline
\end{tabular}

(Sendstad 1978). If a root respiration of approximately $50 \%$ is assumed, then $216 \mathrm{Kcal} / \mathrm{m}^{2} / \mathrm{yr}$ is liberated by the heterotrophic food chain each year. This implies that approximately $26 \mathrm{~g}$ microbial mass have been produced on this site. In energy terms this means approximately $130 \mathrm{Kcal}$. Compared to the data given in Table 3, it can thus be seen that the Collembola ingests between $11 \%$ and $17 \%$ of the microflora production.

The Collembola community is estimated to represent about $70 \%$ of the total detritovores/fungivores invertebrate biomass of the unaffected lichen heath (Sendstad 1978). If the data for Collembola consumption are extrapolated to the whole fungivores/detritovores biota, the total ingestion of these invertebrates may be estimated to be between $16 \%$ and $24 \%$ of the microbial production. It is still an open question whether this grazing intensity has any regulating effect on the activity of the soil microflora. These results do, however, show that the heterothropic foodchain in the soil, in a complicated way, may be affected by artificial changes in the plant cover.

It is finally demonstrated that a removal of the plant cover does promote an overall, loss of organic matter and macronutrients from the pastures (Table 1). Whatever the reasons for these effects, these losses will eventually decrease the potential for plant production. A comprehension of the total effects caused by a destruction of the lichen plant cover must consequently be based on a longterm understanding of soil erosion, combined with an understanding of soil ecology at the site.

The long-term goal of this kind of research will be to see at what level of ruminant grazing intensity, an abnormal rate in the release of nutrients may be experienced, and at what corresponding state we then find the soil heterotrophic food chain. The state of art of soil ecology does not permit us to make any firm statement about the effects of reindeer overgrazing in the arctic tundra. The present data do indicate, however, that we have to be aware of the possibility of a whole spectrum of interactions between the reindeer and its environment.

\section{Literature Cited}

Addsion, J.A. 1977. Population dynamics and biology of Collembola on Truelove Lowland. In: L.C. Bliss (ed.) Truelove Loweland Devon Island, Canada: A High Arctic Ecosystem. The University of Alberta Press. 714 p.

Billing, W.D., G.R. Peterson, G.R. Shaver, and A.W. Trent. 1977. Root growth, respiration, and carbon dioxide evolution in an arctic tund ra soil Arctic and Alpine Res. 2:129-137.

Brattbakk, I. and O.I. R $\phi$ nning. 1978. Rikt planteliv langt mot nord. Forskningsnytt 8:44-51. (in Norwegian).

Harding, D.J.L., and R.A. Stuttard. 1974. Microarthropods. In: C.H. Dickenson and G.J.F. Pugh (eds.) Biology of Plant Litter Decomposition. Part 2. Academic Press. 489-532.

Hegstad, A. 1978. Edderkopper pa Svalbard, Hovedfagsoppgave i spesiell Zoologi. Univ. i. Trondheim. Unpublished theses, in Norwegian. $115 \mathrm{p}$.

Howard, P.J.A., and D.M. Howard. 1976. Respiration, litter nutrients, and soil organic matter in grazed and ungrazed upland limestone grassland. Merlewood Res. and Dev. Pap. No. 67. 12 p.

Lusby, G.C. 1970. Hydrological and biotic effects of grazing vs. nongrazing near Grand Junction, Colorado. J. Range Manage. 12:83-87.

MacFayden, A. 1962a. Energy flow in ecosystems and its exploitation by grazing. In: D.J. Crisp (ed.) Grazing in Terresetrial and Marine Environments. The British Ecological Society, Blackwell. 322 p.

MacFayden, A. 1962 b. Improved funnel-type extractors for soil arthropods. J. Ecol. 30:171-184.

Odum, E.P. 1971. Fundamentals of Ecology. 3rd edition, Philadelphia. London. Toronto. $574 \mathrm{p}$.

Pegau, R.E. 1970. Effect of reindeer trampling and grazing on lichens. J. Range Manage. 23:95-97.

Rauzi, R., and C.L. Hanson. 1966. Water intake and runoff as affected by intensity of grazing. J. Range Manage. 19:351-356.

Rauzi, F., C.L.FLy, E.J. Dyksterhuis. 1968. Water intake on midcontinental rangeland as influenced by soil and plant cover. U.S. Dep. Agr. Tech. Bull 1390. 58 p.

Reichele, D.E. 1969. Energy and nutrient metabolism of soil and litter invertebrates. In: P. Duvigneaud (ed.) Productivity of Forest Fcosystems. Ecology and Conservation. Proc. Bryssel Symp. 1969. Paris: Unesco 1971. 465-477.

Sendstad, E. 1977. Notes on the Collembola communities in some major plant-sociological associations at Spitsbergen, Svalbard. Norw. J. Ent. 23:143-148.

Sendstad, E. 1978. $\emptyset$ kologiske studier pä Svalbard II. Frcinbeiter, crosjon, jorbunns $\phi$ kologiske prosesser. SINTEF rapport Nr. STF21 A78162. (in Norwegian) 47 p.

Smeins, F.E. 1975. Effects of livestock grazing on runoff and erosion. Watershed Management Symp., Logan, Utah. 267-274

Welch, D., and M. Raw 1964. The early effects of excluding sheep from high level grasslands in the north pennines. J. of Anim. Ecol. 1:281-300.

Whittaker, J.B. 1974. Interactions between fauna and microflora at tund ra sites. In: A.J. Holding \& al. (ed.) Soil Organisms and Decomposition in Tundra, ed. A.J. Holding et al., Stockholm. 183:196.

Willard, J.R. 1973. Soil invertebrates and minor insects III Collembola. Population and Biomass. Matador Proj. Tech. Rep. No. 19.

Widden, P. 1977. Microbiology and decomposition on Truelove Lowland. In: L.C. Bliss (ed.) Truelove Lowland, Devon Island, Canada A High Arctic Ecosystem. The Univ. of Alberta Press. 714 p.

\section{Authors Omitted}

Authors' names were inadvertently omitted for the article entitled "Seasonal Vegetative Establishment and Shoot Reserves of Eastern Gamagrass" in the July 1981 issue. They are C.L. Dewald and Phillip L. Sims. Our apologies. 